\title{
New communication practices on the radio and in the audiosphere
}

\author{
Introduction
}

Radio and all the culture texts that are created in that medium constitute one of the components of human sound space. The changing auditory environment is filled with diverse forms of communication definable as a result of progressing mediatisation and technological advance. The auditory medium is similar to a lens focussing all the changes occurring in contemporary culture, while the elements composing the auditory space have become the subject of interest of audio-visual anthropology, which studies audio and visual spaces, and which is a modern, interesting, and original science ${ }^{1}$.

This study is devoted to the discussion of radio-based forms and modes of communication which have been developed thanks to various technical developments and the changing type of culture, considering the changes occurring thanks to the presence of new media in our culture. Therefore, the goal of the article is to outline the new practices and modes of audio communication with particular focus on the radio as a medium of a strictly auditory nature. As the starting point, I consider the contemporary audiosphere ${ }^{2}$, which constitutes

\footnotetext{
* Ph.D., e-mail: joanna.bachura@gmail.com; Chair of Journalism and Social Communication, Faculty of Philology, University of Lodz.

${ }^{1}$ Vide: "Przestrzenie wizualne i akustyczne człowieka. Antropologia audiowizualna jako przedmiot i metoda badań”, A. Janiak, W. Krzemińska, A. Wojtasik-Tokarz (eds.), Wydawnictwo Naukowe Dolnośląskiej Szkoły Wyższej Edukacji TWP we Wrocławiu, Wroclaw 2007.

${ }^{2}$ The audiosphere, as stipulated by Maryla Hopfinger, "is the human sound environment [which] changes with civilisational transformations, and the development of sound recording, processing and creating technologies adjusting to cultural changes" (M. Hopfinger, "Literatura i media. Po 1989 roku”, Oficyna Naukowa, Warsaw 2010, p. 141). Vide: E. Pleszkun-Olejniczakowa, "Przyczynek do planu klasztoru kultury na podstawie badań radiowych przekazów artystycznych", Acta Universitatis Lodziensis. Folia Litteraria Polonica 2014, Issue 1 (23), pp. 7-42 and T. Misiak, "Audiosfera w kulturze współczesnej. Próba przybliżenia pojęcia“, Przeglad Kulturoznawczy 2010, Issue 1 (7), pp. 62-74.
} 
the auditory part of the audio-visual culture, and the influence of technological changes on radio communications, artists, and listeners. I shall attempt to answer the question what happens at genre fringes. How in a situation when one is faced with new technology, the multimedia world, and virtual reality, one can reflect on fiction and non-fiction genres on the radio? The development of new technologies, internet and digital radio, podcasts and cloudcasts, and internet sound-based services often constitute a source of inspiration for that which is traditional, thus renewing the object of respective study. The inclusion of new phenomena within widely understood auditoriness has a rescuing nature for traditional forms, and, at the same time, offers new opportunities for creators, and thus an area for research for media scientists and literary critics.

\section{The identity of today's radio}

The question about the identity of today's radio may result in many debates, which will surely bring no single answer. In the face of the ongoing communicational transformations, the emergence of new technologies, which are eagerly used by the auditory medium, as a result of the emergence of heterogenic radio formations and multimedia messages, people often forget about the essence of the radio, about the radio's core identity, i.e. still the auditory message, the richness of sounds, their diversity, and the language of radio communications. All other various elements, such as posting photos, video reports, and the associated blogs, texts or e-mails sent in by the listeners on radio websites, i.e. the activities ancillary to the basic auditory message, cause an expansion of radio's communicational capabilities or the expansion of the limitations of radio genres $^{3}$, yet sound still remains the most important element for radio. Richard Berry $^{4}$ as well as Maura Edmond ${ }^{5}$ wrote convincingly about the new capabilities of supplementing and expanding the sound sphere of the medium, a type of radio visualisation which engages both creators and receivers.

For me, radio's dominant feature, which stabilises it and which has enabled it to persist for almost a century in the communicational sphere, still remains its auditory sphere. Contemporary radio utilises the supplements offered

\footnotetext{
${ }^{3}$ Vide: G. Stachyra, "Współczesne gatunki radiowe jako konglomeraty i kolekcje”, in: "E-gatunki. Dziennikarz w nowej przestrzeni komunikowania", W. Godzic, Z. Bauer (eds.), Poltext, Warsaw 2015, pp. 28-29.

${ }^{4}$ Vide: R. Berry, "Radio with pictures: Radio visualization in BBC national radio", The Radio Journal - International Studies in Broadcast \& Audio Media 2013, Issue 11 (2), pp. 169-184.

${ }^{5}$ Vide: M. Edmond, "All platforms considered: Contemporary radio and transmedia engagement”, New Media \& Society 2015, Issue 17 (9), pp. 1566-1582.
} 
by digitilisation, which is extremely important for its development. It is also a manifestation of the evolution of culture, and the stabilisation of its audio-visual type. The radio conglomerate, is, as proposed by Grażyna Stachyra, "a mix of auditory, textual and image-based forms". At the same time, she stresses the importance, in the case of creating conglomerates and consuming them, of the activity of the listeners/receivers of the message invited to co-create the broadcast content or referred to radio websites in order to delve into more details of the information presented on air or encouraged to visit and co-create a radio programme's fan page on Facebook. The role of contemporary radio receivers has changed: from passive listeners to active participants in culture? Of course not all opportunities offered by the new media are used by listeners. What is important, though, in the context of the discussion of the identity of today's radio, is that the conglomerates "do not operate on the radio as a whole broadcast via a single channel. The radio is for them a bonding agent, though only nominally as the sound nature is not capable of absorbing such elements as images, text, film, and aired content at the same time" ${ }^{8}$. It is sometimes the case that contemporary radio receivers do not listen to the traditional radio message, but eagerly integrate with the community surrounding their favourite station by accessing the popular social media. They consume auditory content in an alternative manner, which, obviously, is a sign of a cultural change and transformation, and the engagement of listeners 9 .

The auditory message with a proprietary language and the capabilities offered by the sound nature of the medium actually sounds most attractive on the radio; it cannot be transferred onto any other medium without losing that which is most important for radio and which actually determines its essence. Nonetheless, one cannot remain indifferent to the presence of multimedia projects, the emergence of heterogenic formations, and the blurring of genre limitations within the media taxonomy, in essence: the appearance of new and original phenomena on the radio which influence and shape its current nature.

\footnotetext{
${ }^{6}$ G. Stachyra, "Współczesne gatunki radiowe...”, p. 28.

${ }^{7}$ Vide: A. Kowalska, "Nowy odbiorca? Przemiany obrazu odbiorcy w wybranych koncepcjach współczesnej kultury”, Oficyna Naukowa, Warsaw 2014.

${ }^{8}$ G. Stachyra, "Współczesne gatunki radiowe...", p. 46.

9 Vide: T. Bonini, "Doing radio in the age of Facebook", The Radio Journal - International Studies in Broadcast \& Audio Media 2014, Issue 12 (1/2), pp. 84-85.
} 


\section{Genre fringes}

Shifting genre limits in the media are a feature of the contemporary communicational sphere. Questions have already been raised regarding the genrelessness of the media ${ }^{10}$. As a result of the blurring of genre limitations the once clear division into fiction and non-fiction has become outdated and is no longer obvious. That division into fictional and referential genres is mainly natural for artistic radio narratives, i.e. reports, radio drama and features. In the contemporary artistic radio genre classified as the so-called auditory literature $^{11}$, there occur transformations resulting from, i.a. the development of technical means, which perfectly illustrate the pervading problem of the blurring of the lines between specific genres, and, at the same time, the influence on contemporary literary culture. The emergence on the radio, or, more broadly, in auditory culture, of fringe works/shows which are non-homogeneous in terms of their genre, and which combine contradictory tendencies: literary fiction with genres considered, at least traditionally, as referential, has been observed. The previously applicable division into radio drama, fiction and reports, and documentaries, has become in the face of the emerging new forms of artistic radio expression a conventional division, though still significant from the point of view of media genology. Genre hybrids emerge. Radio drama readily uses the documentary formula, while radio documentaries "prefer" borrowing the methods typical of fiction genres, thus displaying a relationship with fictional nature and the related dramatic tension.

The genological status of documentary and fictional forms in contemporary culture, including the tendencies and devices associated with expanding their borders, was discussed in two texts: "Literatura audialna między fikcją a niefikcją. 'Upowieściowienie' dokumentu a narracje fikcyjne"12 and "Apetyt na życie. Rozważania o fikcji i prawdzie w dokumencie radiowym"13. Here, I only indicate the significance of the issue.

${ }^{10}$ Vide: G. Ptaszek, "W stronę bezgatunkowości mediów? O funkcji gatunków medialnych w procesie odbioru”, in: "Gatunki i formaty we współczesnych mediach”, W. Godzic, A. Kozieł, J. Szylko-Kwas (eds.), Poltext, Warsaw 2015, p. 35-51.

${ }^{11}$ Vide: M. Hopfinger, op. cit., pp. 131-163.

12 J. Bachura-Wojtasik, "Literatura audialna między fikcją a nie-fikcją. 'Upowieściowienie' dokumentu a narracje fikcyjne", in: "Między sztuką a codziennością. W stronę nowej syntezy (1)”, M. Hopfinger, Z. Ziątek, T. Żukowski (eds.), Instytut Badań Literackich PAN, Warsaw 2016, pp. 184-212.

13 J. Bachura-Wojtasik, "Apetyt na życie. Rozważania o fikcji i prawdzie w dokumencie radiowym" [being printed; "Współczesne media - gatunki w mediach", a monograph]. 


\section{"The new" on the radio}

The supremacy of images is undoubtedly a common experience in contemporary culture. One encounters the expansive character of the elements of the iconosphere every day through photographs, television, the internet, graffiti, tattoos, etc. Some time ago, one could assume that the spoken word and sounds are mere supporting actors suppressed by the image culture. However, today interest in the audiosphere and auditoriness seems to be acquiring a new deeper dimension. We almost long for oral communications, telling stories, and the pleasure of listening to them. John Biewen, an American scholar and university teacher, has stressed that the sense of hearing is the first sense which develops in humans, as early as the antepartum period:

Lying in the darkness of the womb at first we can only hear. We can tell there's something out there - it may be Mom playing Mozart to us with headphones on her belly or having a shouting match in the kitchen with Dad - but we can't see it or smell it or taste it. All we can do is listen and imagine what it may be ${ }^{14}$.

Therefore, already in the mother's womb, we begin to sense the diversity of the surrounding auditory environment. That sense, having formed as the first one, should be developed and nurtured in later life regardless of the type of culture in which one grows up. Even the indisputable fact that we live in an audio-visual culture with a dominant image-based function has not resulted in the disappearance of human auditory needs. In fact, many researchers refer to a renaissance of the spoken word and an interest in human auditory space. One can point to more and more examples of the restoration of sound forms through sound-based projects, interest in so-called oral histor $y^{15}$, the dynamic development of digital radio, or radio's focus on new technologies and the use of the extremely popular podcasts. Further in the article, I shall discuss selected examples of sound projects, and new phenomena and capabilities of contemporary radio, which is open to cooperation with new media. New technologies are not a threat to old, traditional forms, a point which in my opinion is noteworthy. On the contrary, everything that is new in the world of sounds, offers new tools and opportunities for propagating a broadly understood auditoriness. The old and the new do not form oppositions, they rather co-create the auditory communicational space

${ }^{14}$ J. Biewen, "Introduction", in: "Reality Radio. Telling true stories in sounds", University of North Carolina, Chapel Hill, NC 2010, p. 11.

${ }^{15}$ Vide: S. McHugh, "Oral history and the radio documentary/feature: Introducing the COHRD form", The Radio Journal - International Studies in Broadcast \& Audio Media 2012, Issue 10 (1), pp. $35-51$. 
offering their audiences interesting activities to engage in. On the one hand, the need for the creators and authors to identify potential opportunities for shaping the auditory landscape in the form of various projects, and, on the other, the need to undertake comprehensive studies in the audiosphere and its reception seem essential from the point of view of media anthropology and within the perspective of the long-term process of the evolution and transformation of culture.

\section{Sound projects}

One project of academic research into the urban audiosphere and the issue of Wrockaw's auditory landscape was the study prepared by the Soundscape Research Centre, University of Wrocław, established in 2009. Selected aspects of the audiosphere of Wrocław and Lower Silesia have been studied before, since 2004, within the framework of elective specialisation courses. The full name of the project is "Pejzaż dźwiękowy Wroclawia - badania nad audiosferą miasta środ kowoeuropejskiego" (Wroclaw's soundscape. A study of the audiosphere of a Central European city). The interdisciplinary study, with an inclination towards the cultural studies perspective, has postulated, e.g. consideration for the acoustic determinants shaping the phonic landscape of the city, and the auditory reception inquiring about the identity and defining the specific elements of the soundscape. The perceptual aspect, something that Robert Losiak has noted, enables one to pose questions about the relationship between people and their phonic environment, and the significance of the auditory environment on humans and their presence in a specific place in the world ${ }^{16}$. The aesthetic sensitivity and the perception of places within the phonic context (in the form of practical projects of urban planning, architecture and art) has been developed in various locations throughout the world, i.a. Canada, Australia, and Finland. Projects, conferences, and seminars are accompanied by monographic publications, and periodicals specialising in specific themes ${ }^{17}$.

\footnotetext{
${ }^{16}$ Vide: R. Losiak, "Miejskie pejzaże dźwiękowe. Z projektu badań nad audiosferą w doświadczeniu odbiorczym", in: "Przestrzenie wizualne i akustyczne człowieka. Antropologia audiowizualna jako przedmiot i metoda badań”, A. Janiak, W. Krzemińska, A. Wojtasik-Tokarz (eds.), Wydawnictwo Naukowe Dolnośląskiej Szkoły Wyższej Edukacji TWP we Wrocławiu, Wroclaw 2007, pp. 237-246.

${ }^{17}$ Some of the more noteworthy works included: The World Soundscape Project, the efforts of a research team operating in Canada and Western Europe in 1969-1977; 100 Finnish Soundscapes, a project carried out from 2004-2006 at the University of Tampere together with the Finnish Society for Acoustic Ecology; a study project within the scope of geographic research organised in 2008 in Lublin, i.e. National Interdisciplinary Seminary entitled "Dźwięk w krajobrazie - stan i perspektywy badań", organised by the Institute of Earth Sciences, UMCS and the Cultural Land-
} 
An interesting project was developed by Agata Stanisz, an anthropologist at the Institute of Ethnology and Cultural Anthropology, Adam Mickiewicz University in Poznań, who, in 2009, launched a blog "Miasto dźwięków"18 (Soundcity), where she has been presenting fragments of the soundscape of Poznań, as well as of other European cities she has visited. It is an original project of a documentary-ethnographic nature which not only offers a focus on recording the sounds of a city, but is also enriched with a textual and graphic description. Field recording is treated as an element of the ethnographic method there. Therefore, the project matches the Europe-wide project entitled Sounds of Europe ${ }^{19}$, which is focussed on, on the one hand, recording and storing the phonic landscape of cities and, on the other, on depicting various opportunities for creating and using field recordings. The author intends the raw, unprocessed audio material to systematically enrich the soundscape of Poznań, which in turn will help create a sonic map. It is also noteworthy that the sounds recorded by her constitute a part of a Spanish project entitled The freesound initiated by the Musical Technology Group operating at the Department of Information and Communication Technologies, Pompeu Fabra University in Barcelona, the goal of which is to create a database of various sounds acquired through field recording, computer generated or processed, which function based on the Creative Commons Sampling licence. Stanisz concluded that thus everyone "can download [...] a recording and use it freely. That way the fragments of Poznań's soundscape become a part of various musical compositions, podcasts, and radio shows" ${ }^{\prime 20}$.

Urban audioguides are popular in various cities worldwide, consider e.g. the Hackney Hear in London or the Berlin-based Radioortung ${ }^{21}$, which utilises a similar technology. Now is the time for Poland. The idea to create an audioguide, a form well-known to frequent museum visitors, was used by Anna Czyżewska who developed the idea of the Miejska Ścieżka (Urban Path) project ${ }^{22}$. Its goal

scape Commission of the Polish Geographical Society; a National Academic Seminar entitled "Audiosfera miasta" organised in 2010 through the initiative of the Soundscape Research Centre, University of Wrocław, relating to Schafer's thought on soundscape and the assumptions of sound ecology, which resulted in a volume entitled "Audiosfera miasta" [series: Prace Kulturoznawcze], R. Losiak and R. Tańczuk (eds.), Wydawnictwo Uniwersytetu Wrocławskiego, Wroclaw 2012. Other important projects were discussed in the article: R. Losiak, "Słuchanie miasta? Wokół koncepcji badań miejskiej audiosfery", in: "Audiosfera miasta...”, pp. 11-15.

${ }^{18} \mathrm{http}: / /$ miastodzwiekow.blogspot.com [accessed on: 30.01.2017].

${ }^{19} \mathrm{http}: / / \mathrm{www}$. soundsofeurope.eu/ [accessed on: 30.01.2017].

${ }^{20}$ A. Stanisz, "Audiografia i dewizualizacja antropologii w badaniu miejskiej audiosfery", in: "Audiosfera miasta...", p. 100.

${ }^{21}$ Vide: J. Bachura-Wojtasik, "Radio days (are now). The radio marketplace of innovation in the context of audio-visual culture", in: "Radio: the Resilient Medium: Papers from the Third Conference of the ECREA Radio Research Station", M. Oliveira, G. Stachyra, G. Starkey (eds.), Sunderland: Centre for Research in Media \& Cultural Studies 2014, pp. 27-40.

$22 \mathrm{http}: / /$ miejskasciezka.pl/ [accessed on: 30.01.2017]. Visit the website to learn more about the mode of financing of the project and the related fact-based and artistic cooperation. 
is to invite people for a walk around Warsaw wearing headphones to become familiar with its space, and to learn about the city from the point of view of its regular inhabitants, through their memories, anecdotes, and personal stories, not through established guidebooks. Moja Ścieżka.pl is a mobile app enabling people to download sound files, urban audioguides to specific places and boroughs of the capital, which offer themed trips, e.g. Zakochany Żoliborz (Żoliborz In Love), Narodziny Ursynowa (The Birth of Ursynów), Dwudziestolecie Międzywojenne (The Inter War Period), Kryminalna Warszawa (Warsaw of Crime).

Moja Ścieżka.pl along with Szeptany Lublin ${ }^{23}$ (Whispered Lublin), an audioguide to Lublin, have proved that the atmosphere of a city is created by its inhabitants, who decide about the interesting places in it, they indicate places worth visiting, where the best ice creams are served, which children's playground is the most modern; it is regular inhabitants, not actors or celebrities, that become the main heroes of audioguides. Szeptany Lublin is a project by the Homo Faber association. It was established to talk about modern Lublin, i.e. after 1989, in an interesting way. A dozen or so stories, e.g. Lublin Drukarzy (Lublin of Printers), Lublin Kryminalny (Lublin of Crime), Lublin Żydowski (Jewish Lublin), O Przestrzeni Miasta (On Urban Space), Ścieżki Lubelskiej Opozycji (Paths of the Lublin Opposition), is told by people who remember recent history, who were engaged in the June election, the development of democracy, who were engaged in the building of a civil society.

The Jewish heritage of the cities of the Silesian Voivodeship is discussed in an audioguide entitled Opowieści Nieobecnych ${ }^{24}$ (Stories of the Absent), which consists of 60 stories prepared by the Brama Cukermana Foundation in cooperation with Centrum Dialogu Międzykulturowego. It talks about the history and the places associated with the former Jewish communities in Tarnowskie Góry, Gliwice, Zabrze, Bytom, Katowice, Sosnowiec, Będzin, Czeladź, Chorzów, Dąbrowa Górnicza and Żarki. It is supplemented with printed maps with marked locations to which the descriptions refer.

It seems that there are more and more urban guides ${ }^{25}$. It is a quite accessible form of communication, the interest in which has been increasing due to the fact that contemporary users of culture eagerly use mobile apps and download sound

${ }^{23} \mathrm{http}: / /$ szeptany.lublin.pl/pl/ [accessed on: 30.01.2017]. Visit the website to learn more about the mode of financing of the project and the related fact-based and artistic cooperation.

${ }^{24} \mathrm{http} / / / \mathrm{www}$. bramacukermana.com/new/ON/index.html [accessed on: 30.01.2017].

${ }^{25}$ Vide also: audioguide to Sopot - "Krok po kroku z Trójką, Sopot” (Step By Step With Radio Three, Sopot), prepared by Joanna Mielewczyk and Krystian Hanke, journalists at Polish Radio Three http://www.polskieradio.pl/24/308/Artykul/1144934,Tak-powstawal-Trojkowy-audiobooko-Sopocie [accessed on: 30.01.2017]. In June 2015, another audioguide by Radio Three was launched: "Krok po kroku z Trójką, Wrocław". Both CDs are available for purchase at the Polish Radio store http://sklep.polskieradio.pl/Products/12405-krok-po-kroku-z-trojka-sopot.aspx [accessed on: 30.01.2017]. 
files to listen to them anywhere and at a time of their convenience. Audioguides meet those expectations.

Clearly, research into the anthropology of cities has included literary or iconographic sources and documents, yet there has not been any research into the urban auditory sphere. The experience of the urban audiosphere seems to be a new and appropriate direction for research strategies in line with the extended context of anthropological studies, along with a new subdiscipline, i.e. auditory anthropology ${ }^{26}$.

\section{Neo-radio. Podcasting}

Radio understood as a traditional medium has been reborn in a new form utilising the available technology to become a flexible medium opened to the communicational expectations of receivers. Considering the development opportunities offered by it, one might even talk about radio as a new medium since the radio industry is developing in several directions: there is internet radio, digital radio, hybrid radio, an extensive programme range on radio stations, and access to it via various apps, sound platforms, and social media ${ }^{27}$. Today, the reception of radio occurs in conditions chosen by the listener, i.e. an active receiver, who can independently compose the message and its reception at a time of her/his convenience. The convergence of technology and content has considerably transformed the face of the radio medium in terms of broadcasting, distributing the radio signal, and internet services.

Digital radio has been a true milestone in the development of radio technology offering a means of expanding the programme range to include additional profiled stations. In October 2013, Polish Radio launched the first DAB+ broadcast service, starting with the urban areas of Warsaw and Katowice, later expanding the reach, and introduced original digital stations [PR24, Radio Rytm, Radio Dzieciom] ${ }^{28}$. The digital broadcast resulted in activities which supplement the production with new and innovative elements, such as $\mathrm{DSL}^{29}$ and $\mathrm{EPG}^{30}$, while listeners can have an influence on the music being aired.

\footnotetext{
${ }^{26}$ For more on the subject of auditory anthropology and the human immersed in and creating the audiosphere, vide: A. Janiak, "Audialny wymiar codzienności. O celowości badania audiosfery przestrzeni domowej”, in: Audiosfera miasta ..., pp. 91-97.

${ }^{27}$ Vide: M. Edmond, op. cit.

28 Vide: S. Jędrzejewski, "Radio publiczne w Europie. Program - finansowanie - technologia - audytorium", Poltext, Warsaw 2015, pp. 185-186.

${ }^{29}$ Digital Subscriber Line, a popular broadband internet access technology.

${ }^{30}$ Electronic Programme Guide.
} 
In terms of the programming, wrote Paweł Mathia, of Polskie Radio Rytm, for the first time in its history, listeners can decide how often songs are to be aired. That has been made possible thanks to a unique system for voting on one's favourite songs using a website, which is directly connected to the broadcast system ${ }^{31}$.

The advantages of commissioning the DAB + technology, a uniform European broadcasting standard, are discussed by Witold Graboś in: "Radio cyfrowe a polska racja stanu"32. Stanisław Jędrzejewski stresses the fact that digital radio requires listeners to acquire new media competences, and to replace their former receivers with those which can receive digital radio. He notes

that just as digital radio will not oust analogue radio anytime soon, the internet will not replace traditional radio. One can already see that $\mathrm{DAB}+$ digital radio and the internet are, and will remain for many years to come, supplementary technologies for traditional analogue radio, rather than its replacements unless they merge within a new radio technology, e.g. [...] DNS hybrid radio, which integrates analogue FM broadcasting with $\mathrm{DAB}+$ digital broadcasting and the internet ${ }^{33}$.

Internet radio remains a new medium within the contemporary media map, a type of a hybrid, a blend of traditional radio and the new opportunities offered by computers and the internet. Jędrzejewski stresses that "in many cases, internet radio fills the gaps present in the traditional radio broadcasting market, while it satisfies the very specific needs of its listeners" ${ }^{34}$ who seek access to radio stations offering music that is an alternative to that found on traditional broadcasters. Others seek a direct influence on a station's content, and utilise the interactive nature directly and independently creating the radio on the internet ${ }^{35}$. Listeners now have the opportunity not only to receive content, but also to create or co-create it; in short: they possess production tasks.

Internet radio operates on two levels; as a simulcast - a simultaneous broadcast of FM or AM signal via analogue or internet channels, and webcast

${ }^{31}$ P. Mathia, "Kroki milowe techniki Polskiego Radia w latach 1925-2015", in: "Polskie Radio. Historia - program - technika. 90 lat Polskiego Radia”, A. Ossibach-Budzyński (ed.), Polskie radio SA, Oficyna Wydawnicza ASPRA-JR, Warsaw 2015, p. 102.

${ }^{32}$ W. Graboś, "Radio cyfrowe a polska racja stanu”, in: "Polskie Radio. Historia...”, pp. 63-66.

${ }^{33}$ S. Jędrzejewski, op. cit., p. 185. Hybrid radio broadcast via satellites, ground emitters, or cable services, with additional services available on the internet via special websites, are discussed on the following pages: 196-198.

${ }^{34}$ S. Jędrzejewski, op. cit., p. 192.

${ }^{35}$ Vide: S. Nożyński, "Radio internetowe - umiejętność słuchania, możliwość kreowania", in: “Język@ multimedia: dialog - konflikt”, A. Dytman-Stasieńko, J. Stasieńko (eds.), Wydawnictwo Naukowe Dolnośląskiej Szkoły Wyższej, Wroclaw 2012, pp. 341-359. 
- a show available online ${ }^{36}$. This developed in the second half of the 1990s in the United States and it quickly spread around the world thanks to the use of the internet as a distribution channel. It would be difficult to argue against the statement that "internet radio was developed through technological convergence understood as a process of the blending of the technologies specific for traditional electronic media, the ICT industry, and the computer industry" ${ }^{37}$.

As indicated by Stachyra, the mode of receiving the medium has changed. Websites, without which virtually no radio station can exist, offer access to archived shows, which live longer than during just one on-air slot, they include video recordings of selected shows, post photographs, etc., thus enriching the sound-based content with added visual value ${ }^{38}$.

The receivership of internet radio throughout the world has been increasing, particularly through the interactive services of such platforms as Pandora [USA only], Spotify [a music service launched in 2008], Last.fm [a website launched in 2002], Live365.com [a music-focussed social media outlet], and Deezer [launched in France in 2007]. One should also mention Radio Wnet, a Polish internet radio station, launched in 2009, which offers audio content, transcripts of selected sound material, as well as reports and video material ${ }^{39}$. The popularity of social media and the phenomenon of personalised media, where users can, e.g. create playlists using the archive of the website, have resulted in such a huge interest in them, leaving analogue media far behind. Radio broadcasters also eagerly use social media in order to stimulate their audience, and utilise it for promotional purposes.

So why do we talk about neo-radio or new radio? That is because the medium utilises various channels for distributing the radio signal [analogue, digital, internet], it features a whole range of modes of receiving the signal [the internet, mobile phones, mobile devices], richness of the offer, and its availability.

One of the more dynamically developing technologies is podcasting ${ }^{40}$, the beginnings of which date back to $2004^{41}$. In the case of radio, it is "a soundbased show posted on the internet usually in the form of periodic instalments using

\footnotetext{
${ }^{36}$ Vide: M. Oliveira, S. Jędrzejewski, "Od air do web: rzeźbienie radia w sieci...”, in: "Radio i społeczeństwo", G. Stachyra, E. Pawlak-Hejno (eds.), Wydawnictwo Uniwersytetu Marii Curie-Skłodowskiej, Lublin 2011, pp. 48-50. Types of internet radio: radio stream, web stream, radio-on-demand, e-radio, i-radio, blog-radio.

${ }^{37}$ W. Kołodziejczyk, P. Stępka, "Radio internetowe - szanse i wyzwania", Studia Medioznawcze 2006, Issue 2 (25), p. 127.

${ }^{38}$ Vide: G. Stachyra, “Współczesne gatunki radiowe...”, pp. 38-39.

${ }^{39}$ Vide: G. Stachyra, "Radio Wnet: From mainstream to grassroots. A case study of productive listeners", in: "Radio Audiences and Participation in the Age of Network Society", T. Bonini, B. Monclùs (eds.), Routledge, London-New York 2015, pp. 231-251.

${ }^{40}$ The name podcast came from a combination of the words iPod and broadcast.

${ }^{41}$ Vide: A.J. Bottomley, "Podcasting: A Decade in the Life of a 'New' Audio Medium: Introduction”, Journal of Radio \& Audio Media 2015, Issue 22 (2), p. 164.
} 
RSS feed [Really Simple Syndication] [...] Podcasting is also sometimes referred to as off-line internet radio. Off-line because podcasts can be downloaded onto computers or MP3 players and played back at any time" ${ }^{\text {" }}$. Podcasts are saved in the digital format as sound files, usually $m p 3$ or $w m a$, but also ape, $m p c, o g g, r p$. RSS is an alternative method of posting information on the internet to websites.

RSS, as Tomasz Goban-Klas has noted, resembles a subscription: we do not need to constantly visit a website to check whether new information has appeared [e.g. shows saved as files], as they are sent to our computers at the moment they are posted. New forms of posting information on the internet are based on integrating the content with RSS technology ${ }^{43}$.

Jędrzejewski stresses that podcasting is only a form and a method of distributing audio content, not giving selected shows some new value. It is also a good way to expand the reach of a station, promoting it, increasing the engagement and loyalty of its listeners, and strengthening their bond ${ }^{44}$. However, Andrew J. Bottomley has stated that podcasting is something more than just a method of distributing audio content. In the technology, he saw original, often amateur production, from the very start located outside the traditional media industry ${ }^{45}$. Today, one can talk about the huge success of podcasts worldwide, particularly after the emergence of such breakthrough productions as Welcome to the Night Vale $^{46}$ or Serial ${ }^{47}$. Its popularity is increasing, as noted by Kris M. Markman, also thanks to the increased ownership of smartphones and various apps enabling one to download files from the internet ${ }^{48}$. In an article on Serial, Berry convincingly described how podcasts utilise traditional established style conventions, which can be found in such genres as a radio documentary, radio drama, and audiobooks, in order to stimulate and draw the interest of potential receivers of the new form ${ }^{49}$.

${ }^{42}$ M. Oliveira, S. Jędrzejewski, op. cit., p. 49.

${ }^{43}$ T. Goban-Klas, "Radiomorfoza w kontekście ewolucji, adaptacji i konwergencji mediów", Studia Medioznawcze 2006, Issue 3 (26), p. 20. Vide: A.J. Bottomley, "Podcasting: A Decade in the Life...", p. 166.

${ }^{44}$ Vide: S. Jędrzejewski, "Radio publiczne w Europie...”, pp. 203-204.

${ }^{45}$ Vide: A.J. Bottomley, "Podcasting: A Decade in the Life...", p. 166.

46 Vide: A.J. Bottomley, "Podcasting, 'Welcome to Night Vale' and the Revival of Radio Drama”, Journal of Radio \& Audio Media 2015, Issue 22 (2), pp. 179-189.

${ }^{47}$ R. Berry, "A Golden Age of Podcasting? Evaluating 'Serial' in the Context of Podcast Histories", Journal of Radio \& Audio Media 2015, Issue 22 (2), pp. 170-178. The phenomenon of the project was discussed in: D. Richman, "Why 'Serial' is the greatest podcast ever made", 14.11.2014, http://www.telegraph.co.uk/men/the-filter/11230770/Why-Serial-is-the-greatest-podcast-evermade.html [accessed on: 28.01.2017].

${ }^{48}$ Vide: K.M. Markman, "Everything Old is New Again: Podcasting as Radio's Revival”, Journal of Radio \& Audio Media 2015, Issue 22 (2), p. 240.

49 R. Berry, "A Golden Age of Podcasting?". 
The majority of public stations utilise that new technology to offer receivers selected shows free of charge. One cannot forget that the users of podcasting can themselves become podcasters and suppliers of content thanks to streaming audio software. The interactive nature is an important feature of that technology ${ }^{50}$. In 2006, while conducting his study, Berry not only focussed on the transferability, closeness, and the availability of the new media practice, but he also realised that thanks to it "[...] audiences are producers"

Is the developing technology the future of podcasting? It is difficult to offer a definite answer, yet clearly it is one of the paths of the development of the medium, considering the cultural practices of production and consumption of digital audio content ${ }^{52}$, and while retaining that which is most important for radio: the spoken word, music, the mobile nature of the medium, which can accompany us at home or while we travel.

\section{Conclusion}

New phenomena included in broadly understood auditoriness, i.e. multimedia projects, internet and digital radio, podcasts, and sound platforms, supplement the auditory nature of traditional radio, and result in the emergence of new communicational practices. In the context of those phenomena, characteristic of the convergence culture, it is worth seeking an answer to the question about their influence on the content and the quality of audio texts and the emerging new forms. Therefore, one should continue to ask about the shape of contemporary radio, which pro-actively responds to the changes which occur in culture. Today, the notion of radio is often combined with the multimedia message on the internet, with the ability to carry audio files on one's telephone or other small portable devices, while listeners are perceived as users, and co-creators, not just consumers of content. Not only sound and the spoken word, but also the delivery of data and the visual sphere are bound with the future of the radio. The new radio is an interactive medium, personalised with a diverse programme offer, often available on demand. Finally, let us not forget about the essence of the radio, about its underlying goal of stimulating the imagination and triggering the best things in receivers.

\footnotetext{
${ }^{50}$ Vide: S. Jędrzejewski, “Radio publiczne w Europie...”, p. 205.

${ }^{51}$ R. Berry, "Will the iPod kill the radio star? Profiling podcasting as radio", Convergence: The International Journal of Research into New Media Technologies 2006, Issue 12 (2), p. 143.

52 Vide: T. Bonini, “The 'Second Age' of Podcasting: reframing Podcasting as a New Digital Mass Medium", Quaderns del CAC 2015, Issue 41, Vol. 18, pp. 21-30 and G. Stachyra, "Podcasting jako technologia audio. Perspektywy rozwoju", Studia Medioznawcze 2017, Issue 1 (68), pp. 29-42.
} 


\section{Bibliography}

„Audiosfera miasta” [series: Prace Kulturoznawcze], R. Losiak and R. Tańczuk (eds.), Wydawnictwo Uniwersytetu Wrocławskiego, Wroclaw 2012.

Bachura-Wojtasik J., "Apetyt na życie. Rozważania o fikcji i prawdzie w dokumencie radiowym” [being printed; „Współczesne media - gatunki w mediach”, a monograph].

Bachura-Wojtasik J., "Literatura audialna między fikcją a nie-fikcją. 'Upowieściowienie' dokumentu a narracje fikcyjne”, in: „Między sztuką a codziennością. W stronę nowej syntezy (1)”, M. Hopfinger, Z. Ziątek, T. Żukowski (eds.), Instytut Badań Literackich PAN, Warsaw 2016, pp. 184-212.

Bachura-Wojtasik J., "Radio days (are now). The radio marketplace of innovation in the context of audio-visual culture", in: "Radio: the Resilient Medium: Papers from the Third Conference of the ECREA Radio Research Station”, M. Oliveira, G. Stachyra, G. Starkey (eds.), Sunderland: Centre for Research in Media \& Cultural Studies 2014, pp. 27-40.

Berry R., "A Golden Age of Podcasting? Evaluating 'Serial' in the Context of Podcast Histories", Journal of Radio \& Audio Media 2015, Issue 22 (2), pp. 170-178.

Berry R., "Radio with pictures: Radio visualization in BBC national radio", The Radio Journal - International Studies in Broadcast \& Audio Media 2013, Issue 11 (2), pp. 169-184.

Berry R., "Will the iPod kill the radio star? Profiling podcasting as radio", Convergence: The International Journal of Research into New Media Technologies 2006, Issue 12 (2), p. $143-162$.

Biewen J., "Introduction", in: "Reality Radio. Telling true stories in sounds", University of North Carolina, Chapel Hill, NC 2010, p. 11.

Bonini T., "Doing radio in the age of Facebook", The Radio Journal - International Studies in Broadcast \& Audio Media 2014, Issue 12 (1/2), pp. 84-85.

Bonini T., "The 'Second Age' of Podcasting: reframing Podcasting as a New Digital Mass Medium”, Quaderns del CAC 2015, Vol. 18, Issue 41, pp. 21-30.

Bottomley A.J., "Podcasting, 'Welcome to Night Vale' and the Revival of Radio Drama", Journal of Radio \& Audio Media 2015, Issue 22 (2), pp. 179-189.

Bottomley A.J., "Podcasting: A Decade in the Life of a 'New' Audio Medium: Introduction", Journal of Radio \& Audio Media 2015, Issue 22 (2), p. 164-168.

Edmond M., "All platforms considered: Contemporary radio and transmedia engagement", New Media \& Society 2015, Issue 17 (9), pp. 1566-1582.

Goban-Klas T., "Radiomorfoza w kontekście ewolucji, adaptacji i konwergencji mediów", Studia Medioznawcze 2006, Issue 3 (26), pp. 11-26.

Graboś W., "Radio cyfrowe a polska racja stanu”, in: „Polskie Radio. Historia - program - technika. 90 lat Polskiego Radia”, A. Ossibach-Budzyński (ed.), Polskie radio SA, Oficyna Wydawnicza ASPRA-JR, Warsaw 2015, pp. 63-66.

Hopfinger M., "Literatura i media. Po 1989 roku”, Oficyna Naukowa, Warsaw 2010.

Janiak A., "Audialny wymiar codzienności. O celowości badania audiosfery przestrzeni domowej”, in: „Audiosfera miasta” [series: Prace Kulturoznawcze], R. Losiak and R. Tańczuk (eds.), Wydawnictwo Uniwersytetu Wrocławskiego, Wroclaw 2012, pp. 91-97.

Jędrzejewski S., „Radio publiczne w Europie. Program - finansowanie - technologia - audytorium", Poltext, Warsaw 2015.

Kołodziejczyk W., Stępka P., "Radio internetowe - szanse i wyzwania”, Studia Medioznawcze 2006, Issue 2 (25), pp. 126-154. 
Kowalska A., „Nowy odbiorca? Przemiany obrazu odbiorcy w wybranych koncepcjach współczesnej kultury", Oficyna Naukowa, Warsaw 2014.

Losiak R., "Miejskie pejzaże dźwiękowe. Z projektu badań nad audiosferą w doświadczeniu odbiorczym”, in: „Przestrzenie wizualne i akustyczne człowieka. Antropologia audiowizualna jako przedmiot i metoda badań”, A. Janiak, W. Krzemińska, A. Wojtasik-Tokarz (eds.), Wydawnictwo Naukowe Dolnośląskiej Szkoły Wyższej Edukacji TWP we Wrocławiu, Wroclaw 2007, pp. 237-246.

Losiak R., "Słuchanie miasta? Wokół koncepcji badań miejskiej audiosfery”, in: „Audiosfera miasta” [series: Prace Kulturoznawcze], R. Losiak and R. Tańczuk (eds.), Wydawnictwo Uniwersytetu Wrocławskiego, Wroclaw 2012, pp. 11-15.

Markman K.M., "Everything Old is New Again: Podcasting as Radio's Revival”, Journal of Radio \& Audio Media 2015, Issue 22 (2), pp. 240-243.

Mathia P., "Kroki milowe techniki Polskiego Radia w latach 1925-2015”, in: „Polskie Radio. Historia - program - technika. 90 lat Polskiego Radia”, A. Ossibach-Budzyński (ed.), Polskie radio SA, Oficyna Wydawnicza ASPRA-JR, Warsaw 2015, p. 89-102.

McHugh S., "Oral history and the radio documentary/feature: Introducing the COHRD form", The Radio Journal - International Studies in Broadcast \& Audio Media 2012, Issue 10 (1), pp. 35-51.

Misiak T., "Audiosfera w kulturze współczesnej. Próba przybliżenia pojęcia“, Przegląd Kulturoznawczy 2010, Issue 1 (7), pp. 62-74.

Nożyński S., "Radio internetowe - umiejętność słuchania, możliwość kreowania”, in: „Język @ multimedia: dialog - konflikt”, A. Dytman-Stasieńko, J. Stasieńko (eds.), Wydawnictwo Naukowe Dolnośląskiej Szkoły Wyższej, Wroclaw 2012, pp. 341-359.

Oliveira M., Jędrzejewski S., “Od air do web: rzeźbienie radia w sieci...”, in: „Radio i społeczeństwo", G. Stachyra, E. Pawlak-Hejno (eds.), Wydawnictwo Uniwersytetu Marii Curie-Skłodowskiej, Lublin 2011, pp. 47-62.

Pleszkun-Olejniczakowa E., "Przyczynek do planu klasztoru kultury na podstawie badań radiowych przekazów artystycznych", Acta Universitatis Lodziensis. Folia Litteraria Polonica 2014, Issue 1 (23), pp. 7-42.

„Przestrzenie wizualne i akustyczne człowieka. Antropologia audiowizualna jako przedmiot i metoda badań", A. Janiak, W. Krzemińska, A. Wojtasik-Tokarz (eds.), Wydawnictwo Naukowe Dolnośląskiej Szkoły Wyższej Edukacji TWP we Wrocławiu, Wroclaw 2007.

Ptaszek G., "W stronę bezgatunkowości mediów? O funkcji gatunków medialnych w procesie odbioru”, in: „Gatunki i formaty we współczesnych mediach”, W. Godzic, A. Kozieł, J. Szylko-Kwas (eds.), Poltext, Warsaw 2015, p. 35-51.

Richman D., "Why 'Serial' is the greatest podcast ever made”, 14.11.2014, http://www.telegraph. co.uk/men/the-filter/11230770/Why-Serial-is-the-greatest-podcast-ever-made.html [accessed on: 28.01.2017].

Stachyra G., "Podcasting jako technologia audio. Perspektywy rozwoju”, Studia Medioznawcze 2017, Issue 1 (68), pp. 29-42.

Stachyra G., "Radio Wnet: From mainstream to grassroots. A case study of productive listeners", in: "Radio Audiences and Participation in the Age of Network Society", T. Bonini, B. Monclùs (eds.), Routledge, London-New York 2015, pp. 231-251.

Stachyra G., "Współczesne gatunki radiowe jako konglomeraty i kolekcje”, in: „E-gatunki. Dziennikarz w nowej przestrzeni komunikowania”, W. Godzic, Z. Bauer (eds.), Poltext, Warsaw 2015, pp. 25-49. 
Stanisz A., "Audiografia i dewizualizacja antropologii w badaniu miejskiej audiosfery”, in: „Audiosfera miasta" [series: Prace Kulturoznawcze], R. Losiak and R. Tańczuk (eds.), Wydawnictwo Uniwersytetu Wrocławskiego, Wroclaw 2012, pp. 99-111.

\section{Internet resources}

http://miastodzwiekow.blogspot.com [accessed on: 30.01.2017].

http://miejskasciezka.pl/ [accessed on: 30.01.2017].

http://sklep.polskieradio.pl/Products/12405-krok-po-kroku-z-trojka-sopot.aspx [accessed on:

30.01.2017].

http://szeptany.lublin.pl/pl/ [accessed on: 30.01.2017].

http://www.bramacukermana.com/new/ON/index.html [accessed on: 30.01.2017].

http://www.polskieradio.pl/24/308/Artykul/1144934,Tak-powstawal-Trojkowy-audiobook-o-So-

pocie [accessed on: 30.01 .2017$]$.

http://www.soundsofeurope.eu/ [accessed on: 30.01.2017].

Joanna Bachura-Wojtasik

New communication practices on the radio and in the audiosphere

(Summary)

For the past decade or so, internet radio, podcasts, mobile sound apps, and digital libraries of audio content have enjoyed increasing popularity among researchers and receivers of culture. Radio, similarly to other traditional media, often experiments with the opportunities offered by the new media technologies enabling the emergence of new communicational practices.

As a starting point, I consider the contemporary audiosphere, which constitutes the auditory part of the audio-visual culture, and the influence of technological changes on radio communications, artists, and receivers. I attempt to answer the question, what happens at genre fringes? What are the characteristic features of the emerging forms? How, when one is faced with new technology, the multimedia world, and virtual reality, can one reach a reflection on the fiction and non-fiction genres on the radio? The expansive character of new technologies is often the source of inspiration for that which is traditional, thus renewing the object of its study. The inclusion of new phenomena within the widely understood auditoriness has a rescuing nature for traditional forms, and, at the same time, offers new opportunities for creators, and thus an area of research for literary scientists, media scientists and literary critics.

Keywords: audiosphere, internet radio, podcast, sound apps, new media, radio genres. 